\title{
Bees of the Euhesma crabronica species-group (Hymenoptera: Colletidae: Euryglossinae)
}

\author{
Elizabeth M. Exley \\ Department of Zoology \& Entomology, The University of Queensland, \\ St. Lucia, Queensland 4072, Australia
}

\begin{abstract}
Seven endemic Australian species of Euhesma bees are described as new: E. evansi, E. lucida, E. sulcata, E. thala, E. undeneya, E. wowine and $E$. yeatesi. Line drawings and a key to females enable separation of species. Known distributions are mapped.
\end{abstract}

\section{INTRODUCTION}

The primitive bee family Colletidae is better represented in Australia than in any other continent. Of its three subfamilies, the Euryglossinae is entirely endemic with large numbers of species still being discovered and described. Recent collections from Western Australia contain many new species particularly in the genus Euhesma Michener. This taxon was proposed by Michener in 1965 as a subgenus of Euryglossa Smith for all the species that did not fit easily elsewhere. It was subsequently (Michener, 2000) raised to genus level and remains so numerous and varied its study is being tackled in manageably sized natural species-groups.

Euhesma crabronica (Cockerell) was described from Brisbane in 1914. It is now clear at least one other species in Queensland and several in Western Australia share characteristics. A "like-species" group based on morphology is considered here as the Euhesma crabronica species-group.

Those associations recorded show females on flowers of the plant family Myrtaceae which remains typical for Euryglossinae although recent collections from other plant families, particularly in Western Australia, are revealing many new species. One natural grouping of species based on association with Eremophila flowers was recently published (Exley, 1998).

Among the many populations of previously unknown species of euryglossines are large $(>6$ $\mathrm{mm}$ ) robust bees in which the head and mesosoma are coarsely and strongly punctate, the propodeum in profile is almost completely vertical, the inner hind tibial spur is pectinate and the wing venation is striking with the anterior side of the second submarginal cell of the forewing much shorter than the posterior side, and the second transverse cubital vein strongly curved or sinuate.

Three species with these characters were described in three genera: Euryglossa crabronica Cockerell 1914, Euryglossimorpha abnormis Rayment 1935 and Dasyhesma robusta Michener 1965. Michener (1965) placed the first two in separate subgenera of Euryglossa: E. (Euhesma) crabronica and E. (Dermatohesma) abnormis. Subsequently, Michener (2000) considered abnormis and robusta to be species in one genus Dasyhesma Michener, 1965.

At least 32 new species share the characteristics given above. The females of seven of them are striking, black bees about $10 \mathrm{~mm}$ long with yellow markings laterally on the metasomal terga. They are similar to E. crabronica and with it are considered here a species-group of Euhesma. This generic placement may change when more groups in Euhesma are revealed and better understood.

Bees of the other new species that show the characters above are smaller and differently coloured and many are currently considered Dasyhesma spp.

\section{METHODS}

In descriptions of species, "relative head measurements" express concisely the size relation between measurements on one head. As most specimens are females, the key presented is for females.

New species names except evansi and yeatesi are to be treated as nouns in apposition to Euhesma.

Abbreviations used are: ANIC, Australian National Insect Collection, Canberra; BMNH, The Natural History Museum, London; KU, Snow Entomological Collection, University of Kansas, Lawrence; LACM, Los Angeles County Museum of Natural History, Los Angeles; MCZ, Museum of Comparative Zoology, Harvard; MV, Museum of Victoria, Melbourne; QM, Queensland Museum, Brisbane; UQIC, University of Queensland Insect Collection, Brisbane; WAM, Western Australian Museum, Perth. 


\section{Euhesma crabronica species-group}

\section{Description}

Length of female about $10 \mathrm{~mm}$, head wider than long with antennae at about middle of face; head and mesosoma coarsely and strongly punctate; propodeum in profile almost completely vertical; forewing (Figure 1) with macrotrichia plentiful, pterostigma much shorter than costal margin of marginal cell, prestigma nearly as long as pterostigma from its base to base of Rs, second submarginal cell with anterior side much shorter than posterior side, junction of posterior side with second recurrent vein about two-thirds along its length base to apex, second transverse cubital vein curved or sinuate; dorsal surface of fore basitarsus of females flat, shining, almost hairless, with outer lateral margin with a row of forwardly bent setae (Figure 2); inner hind tibial spur pectinate, basitibial plate of females completely bounded by carinae. In those males seen, length is about $7 \mathrm{~mm}$, there are long hairs on the volsellae of the genitalia (Figure 8), the seventh gastral sternum has four somewhat odd lobes (Figures 5,9) and the eighth gastral sternum has a distinctively expanded head on a narrow shaft and a strong keel forward from the spiculum (Figures 6, 10).

Despite intraspecific variability in colour markings, the use of colour characters in the key is justified. As now understood, the crabronica speciesgroup contains at least eight species.

Key to females of the Euhesma crabronica speciesgroup

1. Head wholly black E. yeatesi sp. nov.

Head black with yellow markings 2

2(1). Mesoscutellum yellow E. thala sp. nov.

Mesoscutellum black 3

3(2). Clypeus yellow and black with yellow marking somewhat anchor-shaped as in Figure 3 E. evansi sp. nov.

Clypeus almost entirely yellow

.. 4

4(3). Distal two-thirds of forewing infuscate; metasomal terga polished between large obvious punctures

E. lucida sp. nov.

Distal two-thirds of forewing not infuscate; metasomal terga minutely roughened, dull, punctures not obvious .

5

5(4). Metasomal foveae linear, furrowed, 9 or 10 times as long as wide ........ E. sulcata sp. nov.

Metasomal foveae flat, curved, 2-5 times as long as wide

6(5). Mandibles black; forewing with anterior half of marginal cell and wing beyond lightly infuscate E. undeneya sp. nov
Mandibles yellow on at least outer surface; no infuscation on forewing 7

7(6). Supraclypeal area yellow on lower half; Western Australia ........... E. wowine sp. nov.

Supraclypeal area black; eastern Australia ...... E. crabronica

\section{Euhesma crabronica (Cockerell)}

Figures 4, 5, 6

Euryglossa crabronica Cockerell, 1914, pp. 142, 143.

Euryglossa (Euhesma) crabronica Cockerell: Michener, 1965 , p. 91.

Euhesma crabronica (Cockerell): Michener, 2000, p. 216.

\section{Material Examined}

Holotype

Australia: Queensland: $q$, Brisbane, 17 October 1913, H. Hacker (QM).

\section{Other Material Examined}

Australia: Queensland: 19 , same data as holotype; others taken in Brisbane by Hacker on the following dates: $1 q, 3$ October 1912; 19,7 October $1913 ; 1 q, 13$ October 1914; $19,60,10$ October 1916; 1 б, 24 October 1916; 1q, 15 October 1917; 1 \% 22 October 1917; 2 ㅇ, 7 November 1917; 2 ㅇ, 8 October 1918 (all in QM); 1 \% , Brisbane, October 1923, G.E. Hardy; $1 \%$, Brisbane, 20 September 1941, I. Common; 19, Caloundra, Deane (UQIC); 19 , Beerwah, 26 October 1958, C.D. Michener (KU); 1 \%, Beerwah, 28 October 1965, J.C. Cardale, on Tristania (UQIC); 2\%, Mt Emlyn, 20 October 1949, J.McQ

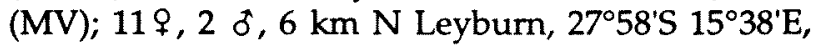
28 October 1985, G. Daniels; $1 \%$, $10^{\star}$ Burrum Heads, $25^{\circ} 11^{\prime} \mathrm{S} 152^{\circ} 36^{\prime} \mathrm{E}, 6$ September 1987, G. and A. Daniels; 19 , Isis district nr. Childers, September 1973, H. Frauca (all in UQIC). New South Wales: 2\%, 7\%, Pilliga Scrub, $9 \mathrm{~km} \mathrm{~N}$ Coonabarabran, 5 December 1976, E.M. Exley and T. Low, on Leptospermum flavescens (UQIC).

\section{Description}

Female

Length about $10.0 \mathrm{~mm}$; wing length about $6.5 \mathrm{~mm}$. Relative head measurements: width 3.4; length 2.9; lower interocular distance 2.0; upper interocular distance 2.0; interantennal distance 0.5 ; antennocular distance 0.5 ; interocellar distance 0.5 ; ocellocular distance 0.4. Anterior margin of clypeus broadly truncate, upper margin of clypeus concave; facial foveae curved towards lateral ocelli, less than $1 / 2$ length of eye; genal area narrower than eye seen from side; antennae short, above middle of 
face; all flagellar segments except last about as wide as long; bastibial plate about $1 / 3$ length of hind tibia; tarsal claws with large sub-median tooth, dorsum of head and thorax with strong punctures, interspaces shining; foveae of second tergum of metasoma about 4 times as long as wide.

Head black with clypeus and mandibles yellow; mesosoma black with pronotal tubercles yellow; legs black with fore tibiae anteriorly and base of mid tibiae yellow; dorsal surface of metasoma black with antero-lateral corners of segments $2-5$ yellow; venter black.

Forewing with veins and pterostigma black, membrane slightly dusky; macrotrichia strong and plentiful over whole wing; second recurrent vein joining second submarginal cell as in Figure 1. Second submarginal cell considerably narrowed towards costa; second transverse cubital vein gently curved.

Pubescence: Sparse, long white hairs on frons, vertex, genae, mesosoma, legs, metasomal sterna, long brown hairs on metasomal tergum 5 .

\section{Male}

Length about $7.5 \mathrm{~mm}$; wing length about $4.5 \mathrm{~mm}$. Relative head measurements: width 2.8; length 2.3; lower interocular distance 1.5; upper interocular distance 1.7 ; interantennal distance 0.5 ; antennocular distance 0.3 ; interocellar distance 0.6 ; ocellocular distance 0.3 . Anterior margin of clypeus broadly truncate; upper margin of clypeus concave; facial foveae about $1 / 3$ length of eye; genal area narrower than eye seen from the side; antennae long, slightly above middle of face, pedicel longer than first flagellar segment, all flagellar segments except first two longer than wide; basitibial plate with carinae and terminal tubercle, about $1 / 3$ length of hind tibia; tarsal claws bifid; frons above antennae with close punctures, dorsum of mesoscutum with close punctures, interspaces shining; foveae of second tergum of gaster about 4 times as long as wide.

Head black with clypeus, paraocular areas to level of antennal sclerites, mandibles (except tip which is red), pale yellow; antennal scape ventrally pale yellow; mesosoma black with pronotal tubercles with yellow spot; legs yellow with all coxae and mid and hind tibiae dorsally, dark brown; dorsal surface of metasoma black with antero-lateral corners of segments 2-6 yellow; venter yellow.

Forewing: As in female.

Pubescence: Long white hairs on clypeus, scapes, frons between antennae, genae, mesosoma and bases of legs; sparse on metasoma.

Terminalia: Figures 5,6.

\section{Euhesma evansi sp. nov.}

Figures 3, 4

\section{Material Examined}

\section{Holotype}

Australia: Western Australia: $q$, Nilemah Sta, 50 mi S Denham, 8-9 October 1969, H. Evans, R.W. Matthews (MCZ).

\section{Paratypes}

Australia: Western Australia: $6 q .1 \hat{0}$, same data as holotype (MCZ, LACM, UQIC).

\section{Other Material Examined}

Australia: Western Australia: $5 q, 9 \mathrm{~km}$ NNE of

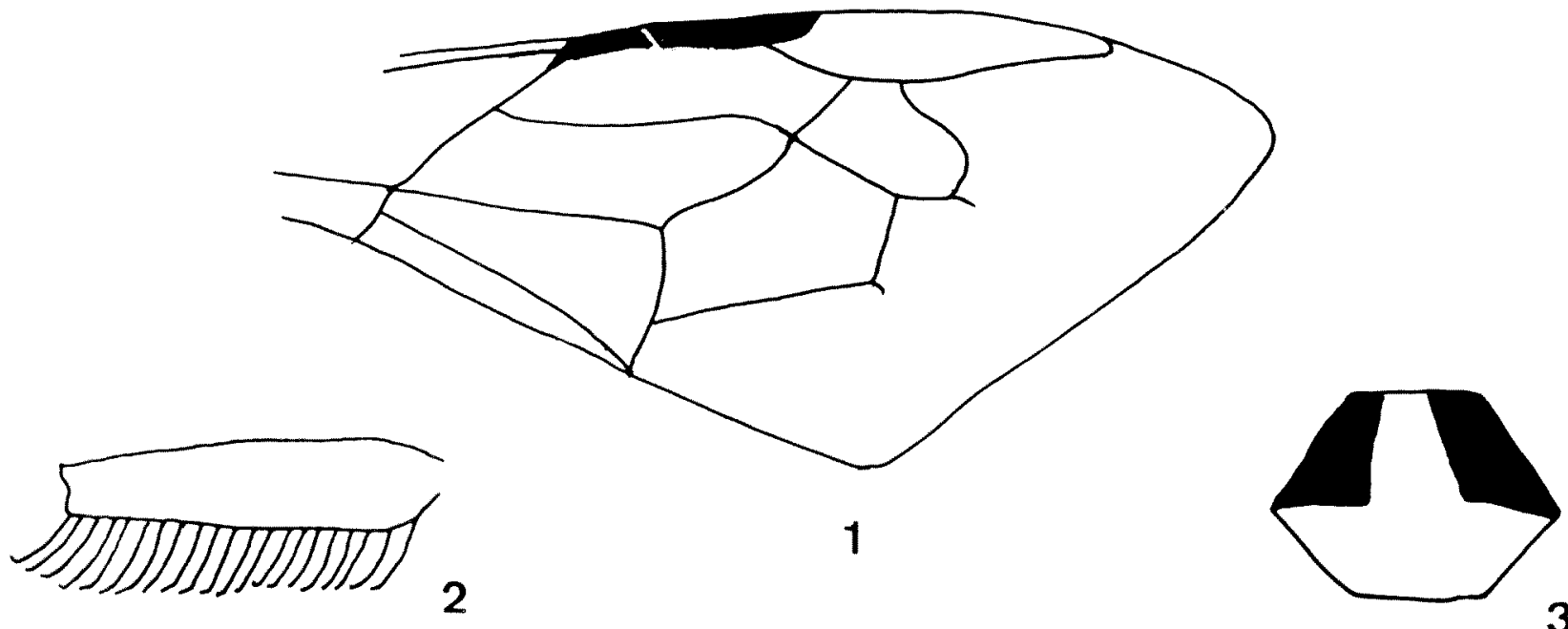

Figures 1-3 1, Portion of forewing of Euhesma evansi; 2, Basitarsus of foreleg of Euhesma wowine, female, distal end at left. Scale line $=1 \mathrm{~mm} ; 3$, Yellow and black "anchor" pattern on clypeus of Euhesma evansi female. Yellow of "handle" continues to supraclypeal area in most specimens. Scale line $=0.5 \mathrm{~mm}$. 


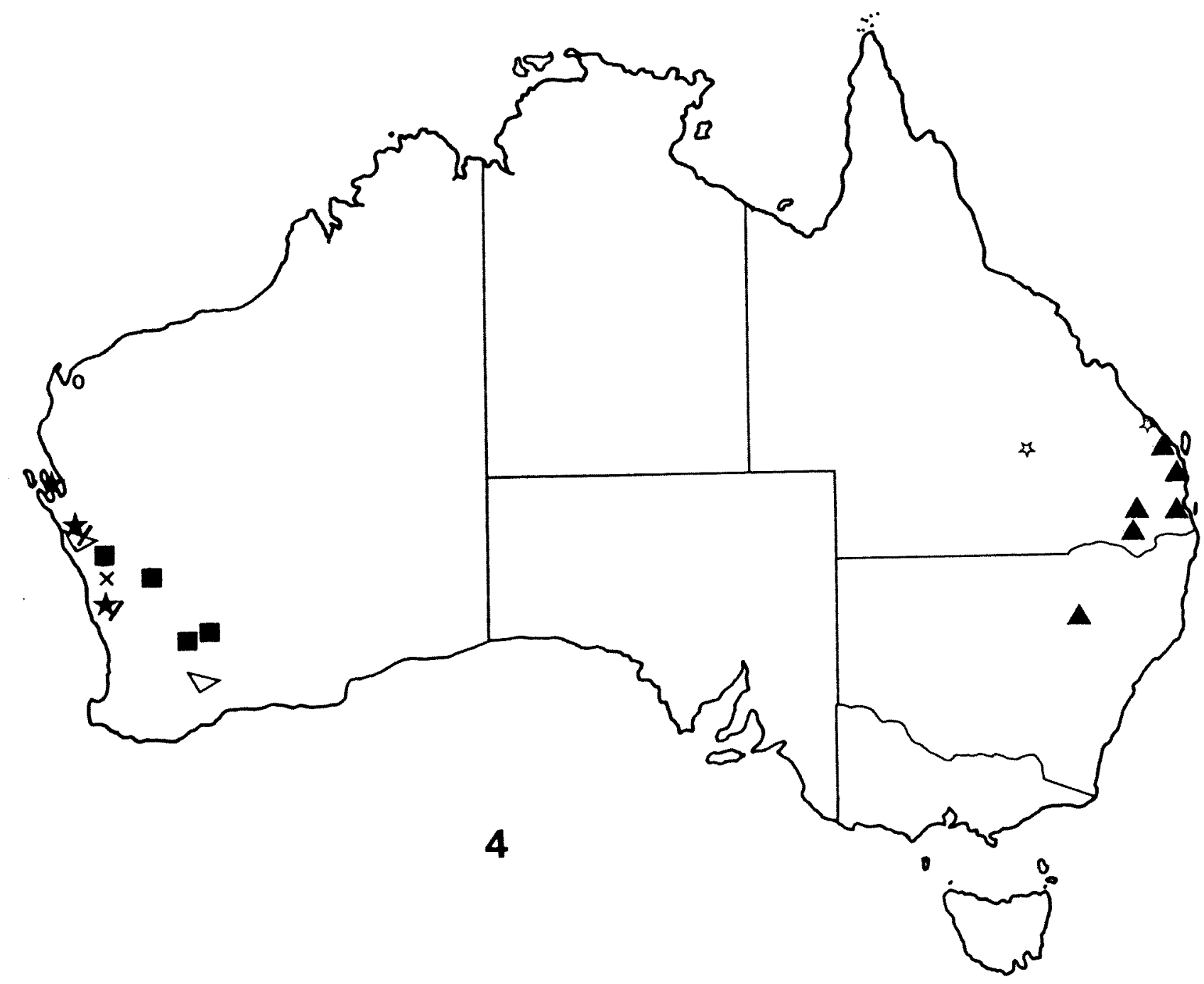

Figure 4 Known distribution of bees of the Euhesma crabronica species-group. $\Delta$ E. crabronica; $\star$ E. evansi; $\nabla$ E. lucida; /E. sulcata; 0 E. thala; $\times$ E. undeneya; $\square$. wowine; of E. yeatesi.

Eurardy HS on NW Coastal Highway 27.30S 114.43E, 25-28 October 1996, T.F. Houston on flowers of Calytrix formosa (Myrtaceae); $4 \%$, some data on flowers of Baeckea sp., 19, $15.5 \mathrm{~km} \mathrm{~N}$ of Eurardy HS on NW Coastal Highway, 27.26S 114.40E, 25 October 1996, T.F Houston, on flowers of Calytrix formosa;, $29,54 \mathrm{~km} 27^{\circ} \mathrm{E}$ of $\mathrm{N}$ from Kalbarri on VP Fence, $27^{\circ} 16^{\prime} 02^{\prime \prime} S 114^{\circ} 25^{\prime} 15^{\prime \prime} \mathrm{E}, 19$ November 1998, T.F. Houston on flowers of Baeckea affin pentagonantha; $39,54 \mathrm{~km}, 27^{\circ} \mathrm{E}$ of $\mathrm{N}$ from Kalbarri on VP Fence, $27^{\circ} 16^{\prime} 02^{\prime \prime} \mathrm{S} 14^{\circ} 25^{\prime} 15^{\prime \prime} \mathrm{E}$, 24 November 1998 on flowers of Melaleuca ; 19 , same data on 19 November on Baeckea blackallii; $19,10 \mathrm{~km}$ WNW of Eurardy HS $27^{\circ} 32^{\prime} 18^{\prime \prime S}$ $114^{\circ} 34^{\prime} 54^{\prime \prime} \mathrm{E}, 21-24$ October 1998, T.F Houston and O. Mueller, on Baeckea blackallii; 2ㅇ, same data on Phymatocarpus porphyrocephalus; $5 \%$, Pinjarrega Lake Nature Res. $23 \mathrm{~km}$ SW Coorow, 3001'40"S $115^{\circ} 49^{\prime} 25^{\prime \prime} \mathrm{E}, 17$ November 1997, T.F. Houston, on flowers of Leptospermum; 19, same data except on flowers of Pileanthus peduncularis peduncularis; $1 \%$, same data except on mauve flowers of Melaleuca; 2\%, Watheroo National Park (NW corner), $30^{\circ} 11 \mathrm{~S}, 115^{\circ} 44 \mathrm{E}, 15-16$ November 1997, T.F. Houston, on flowers of Eremaea violacea (all in WAM).

\section{Description}

Similar to E. crabronica with the following differences:

\section{Female}

Length $10-11 \mathrm{~mm}$; wing length about $7.0 \mathrm{~mm}$. Relative head measurements: width 3.5 ; length 2.8 ; lower interocular distance 1.7; upper interocular distance 2.1; interantennal distance 0.4 ; antennocular distance 0.5; interocellar distance 0.6; ocellocular distance 0.5; foveae of second metasomal tergum about 3 times as long as wide. 
Head and mesosoma with large punctures separated by shining surface; area between punctures greatest on mid scutum, almost no space between punctures on metanotum; anterior metasomal terga dull, minutely roughened with most punctures laterally, sterna with distinct punctures separated by shining surface; propodeal triangle minutely roughened, shining.

Head dark brown/black with the following pale yellow: labrum, mandibles, clypeus anteriorly and posteriorly medianly (Figure 3), anterior corners of paraocular areas, patch on supraclypeal area; thorax and propodeum dark brown; legs dark brown with fore tibiae anteriorly and base of mid tibiae yellow; dorsal surface of metasoma dark brown/black with antero-lateral corners of segments 2-5 yellow; venter dark brown.

Forewing: Prestigma almost as long as distance from base of pterostigma to vein $r$.

Body covered with long white hair with long dark hair on metasomal terga 5 and 6 .

\section{Male}

Length about $7.0 \mathrm{~mm}$; wing length about $4.0 \mathrm{~mm}$. Relative head measurements: width 2.6; length 2.0; lower interocular distance 1.1; upper interocular distance 1.5; interantennal distance 0.9 ; antennocular distance 0.3 , interocellar distance 1.0 ; ocellocular distance 0.4 .

Head black with the following pale yellow; clypeus, supraclypeal area, paraocular areas below level of antennae, labrum, mandibles, antennal scapes ventrally, pedicels, small patch on genae behind mandibles; thorax black with pronotal tubercles and tegulae yellow; legs predominantly clear yellow; dorsal surface of gaster black with antero-lateral corners of segments 2-6 yellow; venter yellow.

Long white hair on head, thorax and trochanters and femora of forelegs.

\section{Remarks}

Specimens included in this species vary (size, colour markings, integument details) and initially were separated into three species corresponding to the three areas marked on the map (Figure 4). The type specimens are from the northern-most population and include the only male recognised. The females are brown rather than black no doubt related to their age. The middle populations are most variable - the diagnostic colouring of the clypeus is not always so distinctly marked, the basal half of $T_{1}$ is amber in most and the normally black areas of the metasoma are orange-red in some. [See also E. sulcata].

\section{Etymology}

The specific name, a noun in the genitive case, honours my friend Howard E. Evans whom I first met on his field trip to Australia in 1969-70 when he collected this species

Euhesma lucida sp. nov.

Figure 4

\section{Material Examined}

\section{Holotype}

Australia: Western Australia: $q, 15.5 \mathrm{~km} \mathrm{~N}$ of Eurardy HS on NW Coastal Highway, 27.26S 114.40E, 25 October 1996, T.F. Houston, on flowers of Calytrix formosa (WAM).

\section{Paratypes}

Australia: Western Australia: $2 \%$, same data as holotype (WAM); 1 , $9 \mathrm{~km} \mathrm{NNE}$ of Eurardy HS, 27.30S, 114.43E, 25-28 October 1996, T.F. Houston, on flowers of Calytrix strigosa (WAM).

\section{Other Material Examined}

Australia: Western Australia: 2 , Dragon Rocks Nature Res. $37 \mathrm{~km} \mathrm{~N}$ of Newdegate, 24-27 November 1996, in flowers of Melaleuca sp. (scabra group); $19,10 \mathrm{~km}$ WNW of Eurardy HS 27 32 ' $18^{\prime \prime} \mathrm{S}$ $114^{\circ} 34^{\prime} 54^{\prime \prime E}, 21-24$ October 1998, T.F. Houston and O. Mueller, on flowers of Calytrix; $19,2 \mathrm{~km} \mathrm{SW}$ Eurardy HS, 27 34'33"S 114 39'19'E, 21 October 1998, T.F. Houston and O. Mueller, swept from flowers of Pileanthus peduncularis ssp. "borealis" of G. Keighery (all in WAM).

\section{Description}

\section{Female}

Length about $11.0 \mathrm{~mm}$; wing length about $7.0 \mathrm{~mm}$. Relative head measurements: width 3.8 ; length 3.3 clypeal length 1.2; lower interocular distance 2.1; upper interocular distance 2.1 ; clypeo-antennal distance 0.4 ; interantennal distance 0.4 ; antennocular distance 0.7 ; interocellar distance 0.5 ; ocellocular distance 0.5 ; metasomal foveae shallow, about 4 times as long as greatest width.

Head, mesosoma and metasoma with large punctures separated by shining surface, punctures closer together on scutum, scutellum and metanotum so that surface appears less shining; labrum and propodeal triangle very minutely roughened, almost glabrous.

Head black, with clypeus, basal half of supraclypeal area, small patch on paraocular areas pale yellow; labrum black; mesosoma black with pronotal lobes and patch anteriorly on tubercles yellow. Wings with basal $1 / 3$ clear, distal $2 / 3$ dark brown.

\section{Remarks}

The females from Dragon Rocks Nature Res. and 
$10 \mathrm{~km}$ WNW of Eurardy HS do not have a yellow patch on the tegulae.

This species is immediately recognised by the wing colour and the polished metasoma.

\section{Etymology}

The specific name is from the Latin and refers to the polished nature of the metasoma between the very numerous punctures.

\section{Euhesma sulcata sp. nov.}

Figure 4

\section{Material Examined}

Holotype

Australia: Western Australia: $q, 9 \mathrm{~km}$ NNE of Eurardy HS on NW Coastal Highway, 27.30S 114.43E, 25-28 October 1996, T.F. Houston, on flowers of Calytrix strigosa (WAM).

\section{Paratypes}

Australia: Westem Australia: $5 \%$, same data as holotype (WAM); 19 , same data as holotype on Calytrix formosa (WAM).

\section{Other Material Examined}

Australia: Western Australia: 19 , Pinjarrega Lake Nature Res, $23 \mathrm{~km}$ SW Coorow, 30 01'40"S, $115^{\circ} 49^{\prime} 25^{\prime \prime} \mathrm{E}, 17$ November 1997, T.F. Houston, on yellow flowers of Calytrix (WAM).

\section{Description}

\section{Female}

Length about $10.0 \mathrm{~mm}$; wing length about $6.0 \mathrm{~mm}$. Relative head measurements: width 3.5 ; length 3.3 ; clypeal length 1.0; lower interocular distance 1.8; upper interocular distance 1.9; clypeo-antennal distance 0.4 ; interantennal distance 0.3 ; antennocular distance 0.5 ; interocellar distance 0.5; ocellocular distance 0.4 ; metasomal foveae clearly grooved, 9 or 10 times as long as wide. Head and mesosoma with large punctures separated by shining surface, metasomal terga minutely roughened, dull.

Head black with clypeus, basal half of supraclypeal area, patch on paraocular areas and mandibles yellow; labrum black; mesosoma black with pronotal lobes partly yellow; metasoma orange-red.

\section{Remarks}

In some, the typical yellow maculations are only partially visible laterally and in all but two specimens some part of the metasomal terga is black. The specimen from Pinjarrega Lake Nature Res. has the typical metasoma of this species-group (black marked with yellow).
The specimens available to me raise the questionDo these bees alter colour with age? I have seen the chrysomelid beetle Aesternia australica Baly completely red orange on emergence and 24 hours later with beautiful blue-green elytra. I suspect these bees might emerge with metasoma red-orange that gradually changes to black.

\section{Etymology}

The specific name is from the Latin and refers to the groove-like metasomal foveae.

\section{Euhesma thala sp. nov.}

Figure 4

\section{Material Examined}

\section{Holotype}

Australia: Western Australia: $q, 16 \mathrm{~km}$ WSW Yannarie River Xing NW Coastal Hwy, 22 ${ }^{\circ} 53^{\prime} 53^{\prime \prime} S$ $114^{\circ} 47^{\prime} 50^{\prime \prime} \mathrm{E}, 30$ September 1997, T.F. Houston and P. Mathiasen, on flowers of Pileanthus limacis (WAM).

\section{Paratype}

Australia: Western Australia: $1 \%$, same data as holotype (WAM).

\section{Description}

\section{Female}

Length about $10.0 \mathrm{~mm}$; wing length about $6.0 \mathrm{~mm}$. Relative head measurements: width 3.4 ; length 2.8; clypeal length 1.0 ; lower interocular distance 2.0; upper interocular distance 2.0; clypeal-antennal distance 0.3 ; interantennal distance 0.5 ; antennocular distance 0.6 ; interocellar distance 0.6 ; ocellocular distance 0.4 . Foveae on 2 nd segment of metasoma about as wide as scape, 5 times as long as wide.

Head and mesosoma with shining surface separating large punctures; metanotum most closely punctate; metasoma with anterior terga dull, minutely roughened, punctures laterally; sterna with large punctures on shining surface; propodeal triangle minutely roughened, shining.

Head black with face below level of antennae (except labrum), basal half of mandibles and antennal scapes ventrally, yellow; mesosoma black with the following yellow: pronotal lobes, patch on pronotum, patch on tegulae, scutellum, patch on metanotum. Metasoma black with basal half of $\mathrm{T}_{2}-$ $T_{5}$ yellow and small patch of yellow on each side of $\mathrm{T}_{1}$.

\section{Remarks}

This species has more yellow colour (scutellum and basal half of metasomal terga) than any other. 


\section{Etymology}

The name "thala" is a Western Australian aboriginal word for bee.

\section{Euhesma undeneya sp. nov.}

Figure 4

\section{Material Examined}

\section{Holotype}

Australia: Western Australia: $q$, Eneabba, 15 October 1985, R.F. McMillan on Verticordia (WAM)

\section{Paratypes}

Australia: Western Australia: $2 q$, same data (WAM, UQIC).
Other Material Examined

Australia: Western Australia: 29, Mingenew, 1522 October 1915, R.E. Turner (BMNH).

\section{Description}

Similar to E. crabronica with the following differences:

\section{Female}

Length about $10.0 \mathrm{~mm}$; wing length about $6.0 \mathrm{~mm}$. Relative head measurements: width 3.5 ; length 2.8 ; clypeal length 1.1 ; lower interocular distance 1.9; upper interocular distance 2.2; clypeo-antennal distance 0.3 ; interantennal distance 0.5 ; antennocular distance 0.6 ; interocellar distance 0.5 ; ocellocular distance 0.5 .
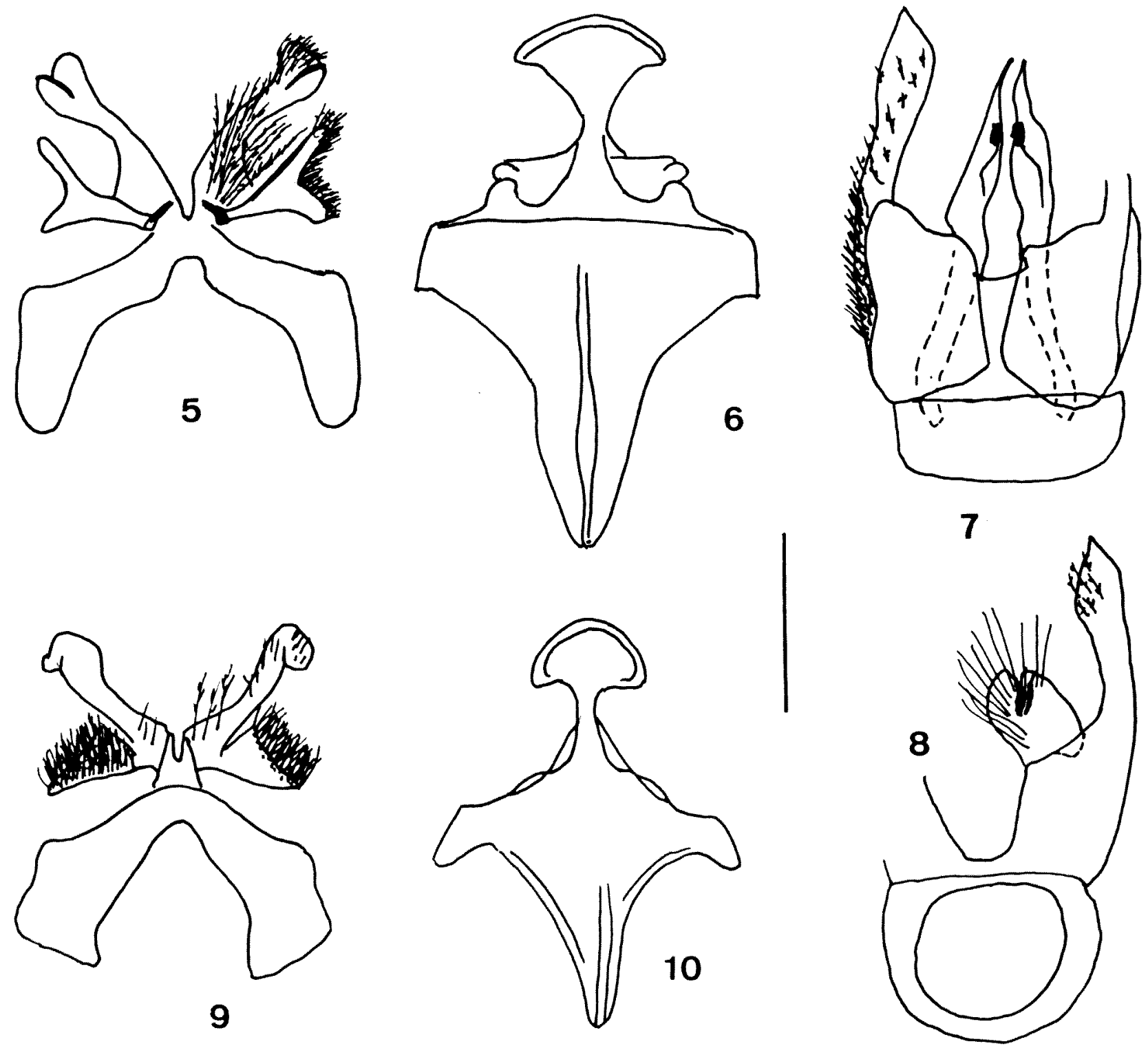

Figures 5-10 Male terminalia: 5, 6, seventh and eighth gastral sterna of $E$. crabronica; 7-10, E. wowine: 7, 8, genitalia (dorsal 7, ventral 8);9,10, seventh and eighth gastral sterna. Scale line $=0.5 \mathrm{~mm}$. 
Metasomal foveae about three times as long as wide; anterior surface of $\mathrm{T}_{1}$ polished, few hairs; metasomal terga lightly punctured, dull; sterna with distinct punctures separated by shining surface; propodeal triangle minutely roughened, shining.

Head black with clypeus and small spot on supraclypeal area yellow; mandibles predominantly black with tips red; mesosoma black; legs black with fore tibiae anteriorly and basal spot on mid tibiae yellow; dorsal surface of metasoma black with yellow maculations on gastral terga 2-5; venter black.

Forewing with anterior half of marginal cell lightly infuscate.

\section{Etymology}

In his description of E. crabronica, the only member of this group previously known, Cockerell referred to its likeness at first sight to a wasp. The name "undeneya" is an aboriginal word for wasp.

\section{Euhesma wowine sp. nov.}

Figures 2, 4, 7-19

\section{Material Examined}

Holotype

Australia: Western Australia: $q, 3.5-5.5 \mathrm{~km}$ S of Yellowdine ( $\left.31^{\circ} 18^{\prime} \mathrm{S} 119^{\circ} 39^{\prime} \mathrm{E}\right), 27$ October 1978, T.F Houston, on flowers of Melaleuca scabra (WAM)

\section{Paratypes}

Australia: Western Australia: 5\%, same data as holotype (ANIC, QM, UQIC); 2\%, same data on flowers of Baeckea ? leptospermoides (WAM); $7 \delta^{\circ}$, same data except flying around Acacia foliage (WAM).

\section{Other Material Examined}

Australia: Western Australia: 19, Weowanie Rock 24 October 1981, R.P. McMillan (WAM); 19 , Moorine Rock, 21-22 October 1978, R.P. McMillan (WAM); 2q, Bodallin, 20 October 1980, R.P. McMillan (one on Leptospermum) (WAM); $2 \%$, $29^{\circ} 29^{\prime} \mathrm{S}, 117^{\circ} 11^{\prime} \mathrm{E}, 11 \mathrm{~km}$ W by S Mt. Singleton, 28 September 1981, I.D. Naumann and J.C. Cardale (ANIC); 19 , same data $29^{\circ} 18^{\prime} \mathrm{S} 117^{\circ} 39^{\prime} \mathrm{E}, 5 \mathrm{~km} \mathrm{SW}$ by W Paynes Find (ANIC); 1, 10 W. Mullewa, 2 November 1958, E.F. Riek (ANIC).

\section{Description}

Similar to E. crabronica with the following differences.

\section{Female}

Length about $10.0 \mathrm{~mm}$; wing length about $7.0 \mathrm{~mm}$. Relative head measurements: width 3.8 ; length 3.0 ; clypeal length 1.1; lower interocular distance 2.2; upper interocular distance 2.3 ; clypeo-antennal distance 0.3 ; interantennal distance 0.5 ; antennocular distance 0.6 ; interocellar distance 0.7 ; ocellocular distance 0.5 .

Head and mesosoma with large punctures separated by shining surface, no large interspace area on mid scutum, anterior metasomal terga dull, minutely roughened, sterna with distinct punctures separated by shining surface; propodeal triangle minutely roughened, dullish.

Head black, with clypeus, basal half of supraclypeal area, small patch of paraocular area anteriorly in some, outer surface of mandibles yellow; mesosoma black with pronotal tubercle partially yellow in some; legs dark brown with fore tibiae anteriorly, apices of middle femora and bases of middle tibiae, yellow; dorsal surface of metasoma black with antero-lateral corners of segments 2-5 yellow; venter dark brown with margins of segments yellowish (entirely yellow in specimens from Weowanie Rock and Bodallin).

\section{Male}

Length about $6.0 \mathrm{~mm}$; wing length about $4.5 \mathrm{~mm}$. Relative head measurements: width 2.8; length 2.1; lower interocular distance 1.5; upper interocular distance 1.7 ; interanntenal distance 0.5 ; antennocular distance 0.4 ; interocellar distance 0.6 ; ocellocular distance 0.4 .

Head black with everything below antennae pale yellow; patch on genae behind mandibles pale yellow; antennal scapes and pedicels pale yellow ventrally; mesosoma black with pronotal tubercles, tegulae and ventral surface between legs I and II, yellow; legs yellow; dorsal surface of metasoma black with yellow markings laterally on segments 2-6; venter yellow.

Long white hair on head, thorax and trochanters and femora of forelegs.

Terminalia. Figures 7-10

\section{Remarks}

The females of $E$. wowine and $E$. crabronica are very similar. The head is wider in $E$. wowine but this is not useful as a key character. The lower half of the supraclypeal area is consistently yellow in $E$. wowine, in some E. crabronica specimens a small splotch of yellow is present there. Males are distinct - the ventral thorax between coxae I and II is yellow in E. wowine, black in E. crabronica.

\section{Etymology}

The name "wowine" is a Western Australian aboriginal word meaning "similar" and refers to the similarity of the females of this species to $E$. crabronica. 
Euhesma yeatesi sp. nov.

Figure 4

\section{Material Examined}

Holotype

Australia: Queensland: $q$, Mt Moffatt National Park, the Chimneys, 14 December 1987, D.K. Yeates (QM).

\section{Paratypes}

Australia: Queensland: 2\%, same data (UQIC); 39 Tantitha, Bundaberg, 18 October 1973, H. Frauca (ANIC).

\section{Description}

Similar to E. crabronica with the following differences:

\section{Female}

Length about $10.0 \mathrm{~mm}$; wing length about $7.0 \mathrm{~mm}$. Relative head measurements: width 3.4 ; length 2.9; lower interocular distance 2.0; upper interocular distance 2.0; interantennal distance 0.5 ; antennocular distance 0.5 ; interocellar distance 0.6 ; ocellocular distance 0.5 ; dorsum of head with interspaces shining, much more strongly punctate than thorax where interspaces are minutely roughened and dullish.

Head black, mandibles black with tips red; mesosoma black with pronotal tubercles yellow; legs black with fore tibiae anteriorly and fore tarsi yellowish; dorsal surface of metasoma black with antero-lateral corners of segments 2-5 yellow, posterior half of segment 5 wholly yellow; venter black.

\section{Remarks}

It is surprising to find a second species in relatively close proximity to $E$. crabronica in southern Queensland. Unfortunately only females are known. They differ from all others in the species-group in that the clypeus is black and the posterior half of metasomal tergum 5 is yellow.

\section{Etymology}

This specific name, a noun in the genitive case, honours David Yeates, a colleague of many years who collected the specimens that alerted me to the species.

\section{REFERENCES}

Cockerell, T.D.A. (1914). A bee resembling a wasp. The Entomologist 47: 142-143.

Exley, E.M. (1998). New Euryglossa (Euhesma) bees (Hymenoptera: Colletidae: Euryglossinae) associated with the Australian plant genus Eremophila (Myoporaceae). Records of the Western Australian Museum 18: 419-437.

Michener, C.D. (1965). A classification of the bees of the Australian and South Pacific Regions. Bulletin of the American Museum of Natural History 130: 1-362.

Michener, C.D. (2000). The Bees of the World. The John Hopkins University Press: Baltimore.

Rayment, T. (1935). A Cluster of Bees. (Endeavour Press: Sydney).

Manuscript received 11 April 2000; accepted 21 December 2001 